\title{
Effect of Irrigation and Fertigation Levels on Cabbage (Brassicaceae Oleracea var. capitata L. Grandslam F1)
}

\author{
Serhat Ayas ${ }^{1, a, *}$ \\ ${ }^{1}$ Yenisehir İbrahim Orhan College, University of Uludag, Yenisehir, 16900 Bursa, Turkey \\ *Corresponding author

A R T I C L E I N F O A B S T R A C T \\ Research Article \\ There are very few studies on cabbage at different fertigation levels in the Marmara Region, where \\ this study was conducted. In this respect, our study has a unique quality. This study was carried out \\ in Bursa Uludag University Yenisehir İbrahim Orhan College application greenhouses in 2014- \\ 2015 years. Five different irrigation treatments (T1: 100\% (full irrigation), T2: 75\%, T3: 50\%, T4: \\ 25\%, T5: $0 \%$ (non-irrigated)) and two different fertigation treatments $\left(\mathrm{F}_{1.0}: 100 \%(100: 100: 100\right.$ \\ NPK fertigation and F0.5: 50\% (50:50:50 NPK) fertigation) were combined together to determine \\ the effects on yield and quality parameters of cabbages. The amount of irrigation water in 2014 and \\ 2015 years varied between $0.0-620.0 \mathrm{~mm}$ and $0.0-660 \mathrm{~mm}$, respectively, while evapotranspiration \\ values varied between $150.0-700 \mathrm{~mm}$ and $180.0-710 \mathrm{~mm}$, respectively. It was determined that \\ irrigation water and fertigation levels, yield and quality parameters of cabbages were affected \\ significantly. In both application years, the highest yield was obtained from $\mathrm{T}_{1} \mathrm{~F}_{1.0}$ treatment as 73.2 \\ and 68.4 tons ha $^{-1}$ respectively, while the lowest yield was obtained from $\mathrm{T}_{5} \mathrm{~F}_{1.0}$ treatment as 3.0 and \\ 3.0 tons ha ${ }^{-1}$, respectively. In 2014 and 2015 years the crop response factor values of cabbage were \\ calculated as 1.20-1.19 and 1.23-1.18, respectively. $\mathrm{T}_{2} \mathrm{~F}_{1.0}$ and $\mathrm{T}_{2} \mathrm{~F}_{0.5}$ treatments can be \\ recommended as the most effective irrigation and fertilization levels of cabbage.
}

\section{Introduction}

Cabbage is produced and consumed in Turkey as a vegetable throughout the year, except for two months. In Marmara Region, which also includes Bursa province, wrap, stew and pickle varieties are generally produced (Vural et al., 2000). Russian researcher Zhukowsky reports that the homeland of cabbage is the Van region of Anatolia and that the world's largest cabbage grows in Van region (Bayraktar, 1981). In 2014-2015 years, 70,997,938 and $70,459,086$ tons of cabbage were produced in the world, respectively. Turkey is placed in 4 th in cabbage production with 22,684,068 and 23,672,902 tons in the world after China, India and USA in 2014 and 2015 years (FAO, 2016). Cabbage is also in the 8 th place in production of fresh vegetables with 34,761 and 33,467 tons, respectively in Bursa province in 2014 and 2015 years (TUIK, 2016). Many studies have been carried out in the world and in Turkey on the irrigation of cabbages (Kızıloğlu et al., 2007; Kızıloğlu et al., 2008; Büyükcangaz, 2018). According to world vegetable production data, cabbage is the 4th most grown product $(70,997,938$ and $70,459,086$ tons) in 2014 and 2015 years. However, according to Bursa and Turkey fresh vegetable production data in 2014 and 2015 years, cabbage is the most grown 8 th $(34,761-33,476$ tons and $733,081-766,675$ tons) product (TUIK, 2017). Since cabbage is grown and consumed very intensely in Bursa of Turkey, there was a need to realize this study.

Irrigation planning is an important management input for optimum efficiency, water use efficiency and economic gains. However, it is also crucial to maintain optimal soil moisture for proper plant growth. In irrigation planning, is defined as when, how much irrigation water will be applied for the plants. In order to answer these two questions, it is necessary to know the important role that climatic conditions play on plants. Therefore, it is very important to develop irrigation planning strategies under local climatic conditions in order to make effective use of limited water resources. Many studies have been carried out in the past on the evaluation and development of irrigation planning techniques under a wide range of soil, crop, climatic conditions and irrigation systems and management. With optimum irrigation planning, water and energy resources are saved and the efficiency of irrigation is increased by 
replenishing the soil moisture to the desired level. Therefore, it is very important to improve irrigation planning under current climatic conditions in order to take advantage of insufficient water resources (Wanjura et al., 1990; Himanshu et al., 2012).

In fertigation, the efficiency of fertilizer use increases due to the direct and frequent application of fertilizers to the plant root area. Therefore, it is possible to reduce the amount of fertilizer applied without compromising the yield of vegetables. With fertigation, fertilizer is applied efficiently by drip irrigation. Plant nutrients are first transported to the plant roots and then to other parts of the plant with fertigation. Fertilizer use is minimized in fertigation applications and cabbages are very sensitive to fertilizer applications. With the application of fertigation with drip irrigation systems, the costs of irrigation and fertilization are reduced, while the nutrient intake in plants is maximized. Optimum fertigation management is possible by knowing the nutrient taken by the fertilization rate to ensure the highest plant productivity (Agrawal et al., 2018; Nikzad et al., 2020). Many studies have been carried out in the world and in Turkey on the irrigation of cabbages (Kızıloğlu et al., 2007; Kızıloğlu et al., 2008; Erdem et al., 2010; Büyükcangaz, 2018; Anaç et al., 2019; Çetin and Akalp, 2019). Previous studies have clearly shown that head yield, head diameter, head weight, head hight dry matter ratio are highly correlated with the irrigation and fertigation levels. There are very few studies on cabbage at different fertigation levels in the Marmara Region, where this study was conducted. In this respect, our study has a unique quality. In this study, the effects of different irrigation and fertigation levels on cabbage yield and quality parameters were researched.

\section{Material and Method}

The research was carried out in plastic covered greenhouse conditions in 2014 and 2015 years. BursaYenişehir area was chosen as the study area and $8 \times 40 \mathrm{~m}^{2}$ dimensional greenhouse was placed in the North-South direction. While the summer months are hot and dry, the winter months are cold and rainy in Yenişehir area. The average annual rainfall and temperature values for the region where the greenhouse experiments were made in 2014 and 2015 were $620.8-784.4 \mathrm{~mm}$ and $14.0-13.3^{\circ} \mathrm{C}$ respectively (Anonymous 2016a). The maximum and minimum temperature values of greenhouse inner air in June-July-August months, which are considered as the plant growing period (92 days) were measured. Maximum and minimum temperature values were $38-38^{\circ} \mathrm{C}$ and $0.9-$ $3.3^{\circ} \mathrm{C}$, respectively in 2014-2015 years (Figure 1 and 2 ). The average relative humidity values for 2014 and 2015 were $75.8-76.8 \%$. The highest and lowest relative humidity values in greenhouse in 2014 and 2015 years were found as $88-87 \%$ and $39-40 \%$, respectively (Figure 3 ). In addition, the highest and lowest radiation values in greenhouse in 2014-2015 years were measured as 1974$1725 \mathrm{~W} / \mathrm{m}^{2}$ and $589-797 \mathrm{~W} / \mathrm{m}^{2}$, respectively (Figure 4) (Anonymous, 2016b).

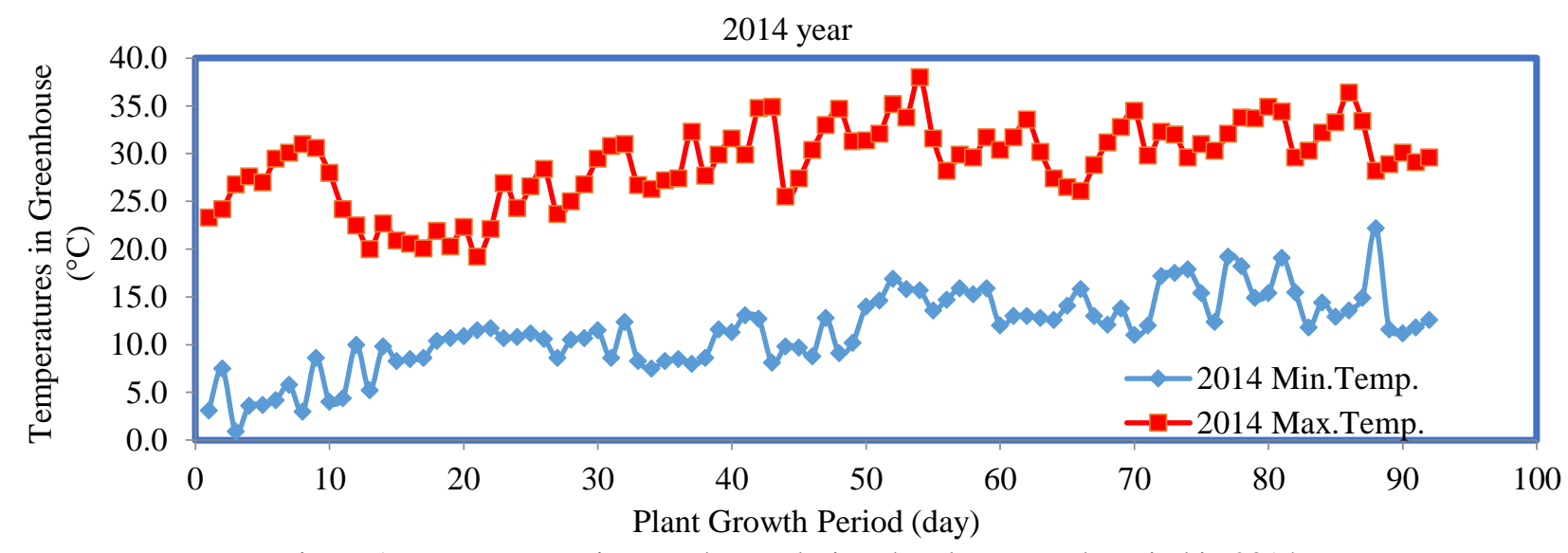

Figure 1. Temperatures in greenhouse during the plant growth period in 2014

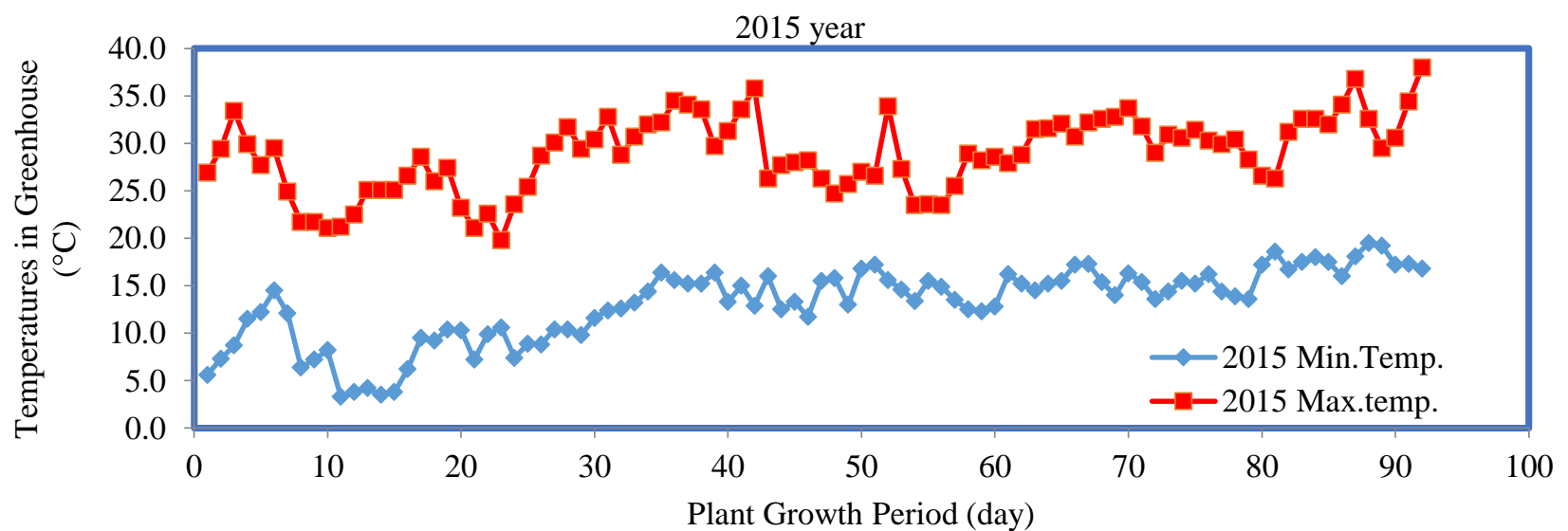

Figure 2. Temperatures in greenhouse during the plant growth period in 2015 


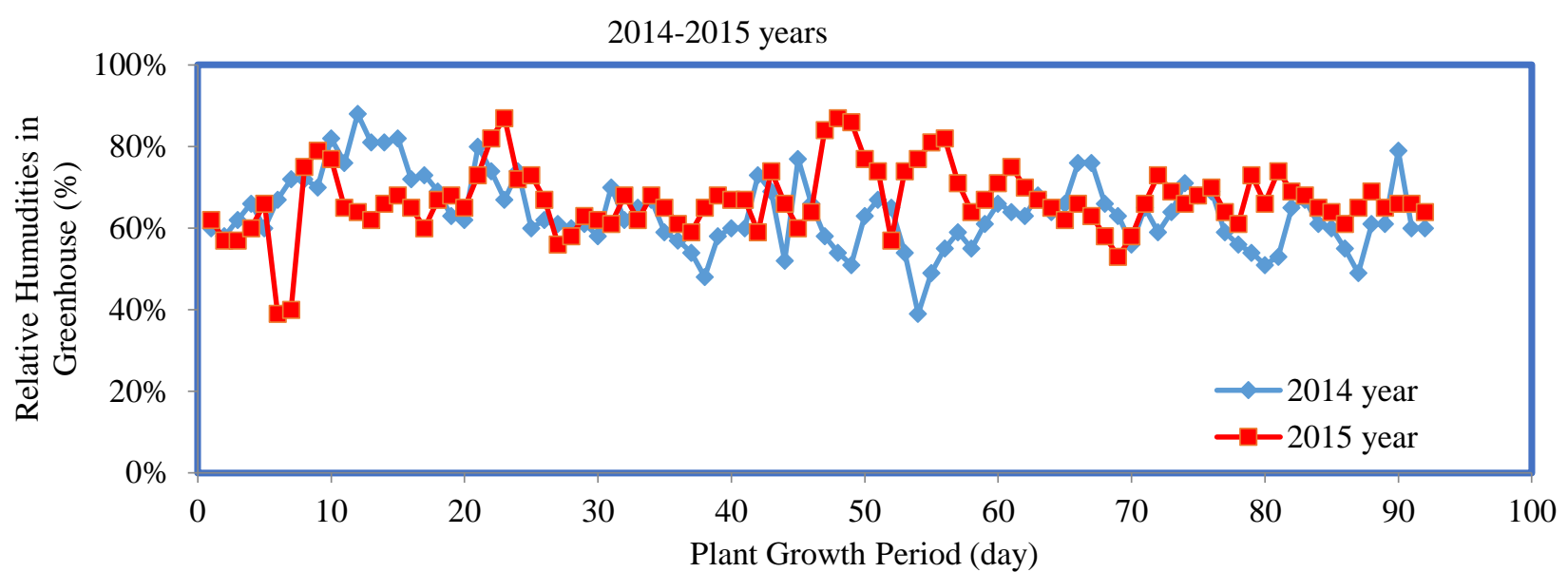

Figure 3. Relative humidities in greenhouse during the plant growth period in 2014-2015 years

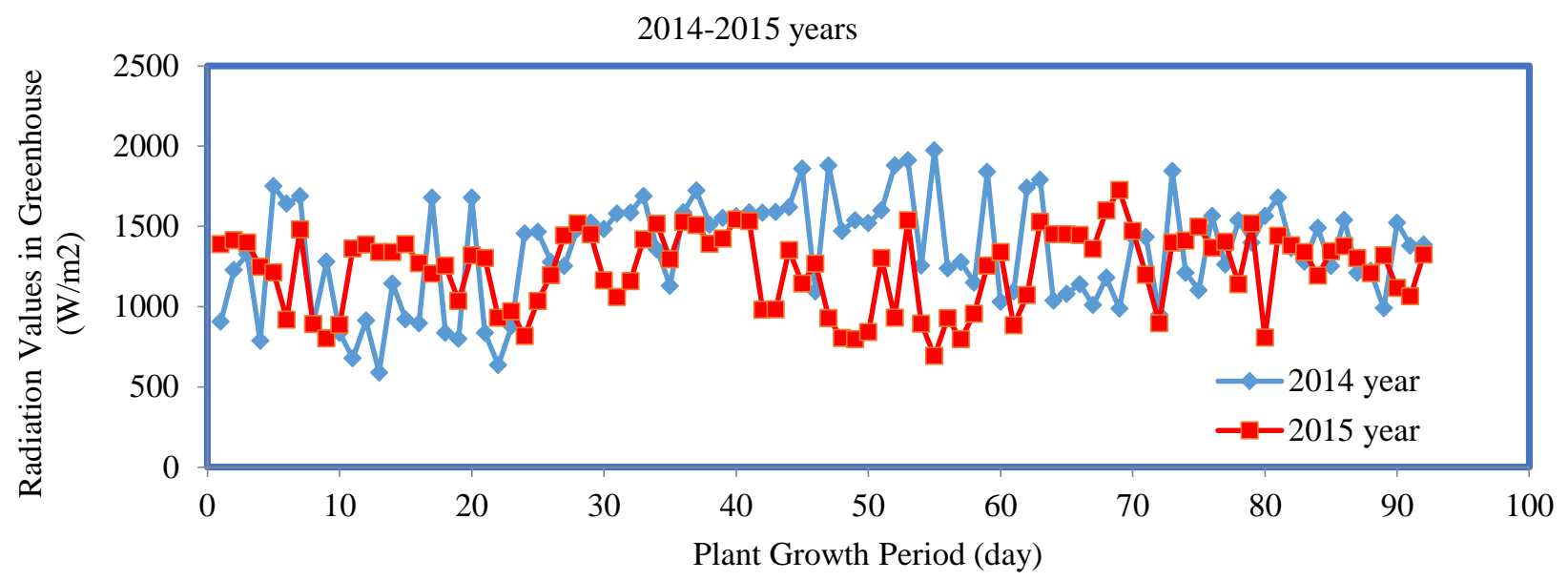

Figure 4. Radiation values in greenhouse during the plant growth period in 2014-2015 years

Table 1. Some specific properties of the experimental soil

\begin{tabular}{l|lccccccc}
\hline $\begin{array}{c}\text { Soil depth } \\
(\mathrm{cm})\end{array}$ & Soil Type & $\begin{array}{c}\text { Unit weight } \\
\left(\mathrm{g} / \mathrm{cm}^{3}\right)\end{array}$ & $\begin{array}{c}\text { Field } \\
\text { capacity }(\%)\end{array}$ & $\begin{array}{c}\text { Wilting } \\
\text { point }(\%)\end{array}$ & $\mathrm{pH}$ & $\begin{array}{c}\text { Total } \\
\text { salt }(\%)\end{array}$ & $\begin{array}{c}\mathrm{CaCO}_{3} \\
(\%)\end{array}$ & $\begin{array}{c}\text { Organic matter } \\
(\%)\end{array}$ \\
\hline $0-30$ & SL & 1.35 & 31.37 & 23.47 & 8.01 & 0.043 & 17.8 & 3.10 \\
$30-60$ & SL & 1.38 & 28.86 & 20.88 & 8,24 & 0.037 & 31.5 & 1.54 \\
$60-90$ & SL & 1.60 & 35.29 & 25.76 & 7.90 & 0.038 & 32.8 & 1.17 \\
$90-120$ & SL & 1.54 & 37.65 & 28.86 & 8.08 & 0.035 & 35.6 & 0.98 \\
\hline
\end{tabular}

SL: sandy loam

The soil of the trial site was sandy-clay and the soil reaction $(\mathrm{pH})$ value vary between 7.90 to 8,08 . Some of the physical and chemical properties of the soil of the experiment site are presented in Table 1.

The production area of Grand Slam $F_{1}$ variety is very large and the growing season is too long. It has a strong root structure and is therefore particularly resistant to cold conditions. Waiting time in the field is long after reaching harvest maturity. Head weight varies between 3-6 kg depending on the frequency of planting. It can be consumed fresh or used as an industrial (Anonymous, 2020).

Mankozeb (80\% WP-350 g/da) and Endosulfan (32.9\% EC/WP-360g/l) were used as chemical drugs against cabbage diseases and insects. In addition, $10 \mathrm{~L}$ ha-1 chlorophyll-ethyl was sprayed against the insects. Two weeks before planting cabbage seedlings in the greenhouse, $100 \mathrm{~kg} \mathrm{ha}^{-1}$ of potassium nitrate $(13 \% \mathrm{~N}$ and $\% 46 \mathrm{~K} 2 \mathrm{O})$ and $1001 \mathrm{ha}^{-1}$ of phosphoric acid $\left(61 \% \mathrm{P}_{2} \mathrm{O}_{5}\right)$ were applied as base fertilizer for $100 \%$ (100:100:100 NPK) fertigation treatment, while $50 \mathrm{~kg} \mathrm{ha}^{-1}$ of potassium nitrate $\left(13 \% \mathrm{~N}\right.$ and $\left.46 \% \mathrm{~K}_{2} \mathrm{O}\right)$ and $50 \mathrm{l} \mathrm{ha}^{-1}$ of phosphoric acid $\left(61 \% \mathrm{P}_{2} \mathrm{O}_{5}\right)$ were applied at 50\% (50:50:50 NPK) fertigation treatment. Six weeks after planting cabbage seedlings in the greenhouse to promote vegetative growth, $40 \mathrm{~kg} \mathrm{ha}^{-1}$ of potassium nitrate $\left(13 \% \mathrm{~N}\right.$ and $\left.\% 46 \mathrm{~K}_{2} \mathrm{O}\right)$ and $201 \mathrm{ha}^{-1}$ of phosphoric acid $\left(61 \% \mathrm{P}_{2} \mathrm{O}_{5}\right)$ were applied for 100\% (100:100:100 NPK) fertigation treatment, while 20 $\mathrm{kg} \mathrm{ha}^{-1}$ of potassium nitrate $\left(13 \% \mathrm{~N}\right.$ and $\left.46 \% \mathrm{~K}_{2} \mathrm{O}\right)$ and 10 $1 \mathrm{ha}^{-1}$ of phosphoric acid $\left(61 \% \mathrm{P}_{2} \mathrm{O}_{5}\right)$ were applied for $50 \%$ (50:50:50 NPK) fertigation treatment. Twelve weeks after planting cabbage seedlings in the greenhouse to promote generative growth, $50 \mathrm{~kg} \mathrm{ha}^{-1}$ of potassium nitrate $(13 \% \mathrm{~N}$ and $\left.\% 46 \mathrm{~K}_{2} \mathrm{O}\right)$ and $201 \mathrm{ha}^{-1}$ of phosphoric acid $\left(61 \% \mathrm{P}_{2} \mathrm{O}_{5}\right)$ were applied for 100\% (100:100:100 NPK) fertigation treatment, while $25 \mathrm{~kg} \mathrm{ha}^{-1}$ of potassium nitrate $(13 \% \mathrm{~N}$ and $\left.46 \% \mathrm{~K}_{2} \mathrm{O}\right)$ and $101 \mathrm{ha}^{-1}$ of phosphoric acid $\left(61 \% \mathrm{P}_{2} \mathrm{O}_{5}\right)$ were applied for $50 \% \quad(50: 50: 50 \quad \mathrm{NPK})$ fertigation 
treatment. In addition, $30 \mathrm{~kg} \mathrm{ha}^{-1}$ urea $(45-46 \% \mathrm{~N})$ fertilizer was applied for $100 \%$ (100:100:100 NPK) of fertigation in order to encourage head development during the generative development period, while $15 \mathrm{~kg} \mathrm{ha}^{-1}$ urea $(45-46 \% \mathrm{~N})$ fertilizer was applied for 50\% (50:50:50 NPK) fertigation treatment.

Cabbage seedlings was planted on June 03 in 2014 and in 2015. Cabbage seedling planting time for Marmara Region is August-September months. However, the planting of seedlings could be applied in June due to the delay in the planning of previous studies carried out in greenhouses. The plant and row spacing applied in the experiment was $0,60 \mathrm{~m}$ and $0,60 \mathrm{~m}$, respectively. Each parcel involved 35 seedlings of cabbage. From the middle of each parcel were harvested 15 plants as sample plants, considering that water would leak from adjacent parcels. The fruit size of the cabbages taken as an example were measured with a caliper tool and the average values was measured. The dry matter ratio of the fruits was specified by drying the samples (at $65^{\circ} \mathrm{C}$ in a drying oven). The dry matter ratio was found by using (AOAC, 2000). The detail of the experimental plot is shown in Figure 5.

Drip irrigation equipment in greenhouse used in the study was given in Figure 6.

The experimental design was determined as a 3replicate and two-factor random block design. 5 different irrigation levels $\left(\mathrm{T}_{1}: 100 \%\right.$ (full irrigation), $\mathrm{T}_{2}: 75 \%, \mathrm{~T}_{3}$ : $50 \%, \mathrm{~T}_{4}: 25 \%, \mathrm{~T}_{5}: 0 \%$ (non-irrigated)) and two different fertilizer treatments $\left(\mathrm{F}_{1.0}: 100 \% \quad(100: 100: 100 \quad \mathrm{NPK})\right.$ fertigation and $\left.\mathrm{F}_{0.5}: 50 \%(50: 50: 50) \mathrm{NPK}\right)$ fertigation were distributed randomly to each block. All treatments are formed as follows: $\mathrm{T}_{1} \mathrm{~F}_{1.00}$ : $100 \%$ irrigation and $100 \%$ (100:100:100 NPK) fertigation, $\mathrm{T}_{2} \mathrm{~F}_{1.00}: 75 \%$ irrigation and $100 \%(100: 100: 100 \mathrm{NPK})$ fertigation, $\mathrm{T}_{3} \mathrm{~F}_{1.00}: 50 \%$ irrigation and 100\% (100:100:100 NPK) fertigation, $\mathrm{T}_{4} \mathrm{~F}_{1.00}: 25 \%$ irrigation and 100\% (100:100:100 NPK) fertigation, $\mathrm{T}_{5} \mathrm{~F}_{1.00}$ : $0 \%$ irrigation and 100\% (100:100:100 NPK) fertigation, $\mathrm{T}_{1} \mathrm{~F}_{0.50}$ : (100\% irrigation and $50 \%$ (50:50:50 NPK) fertigation, $\mathrm{T}_{2} \mathrm{~F}_{0.50}: 75 \%$ irrigation and $50 \%(50: 50: 50 \mathrm{NPK})$ fertigation, $\mathrm{T}_{3} \mathrm{~F}_{0.50}: 50 \%$ irrigation and $50 \%(50: 50: 50 \mathrm{NPK})$ fertigation, $\mathrm{T}_{4} \mathrm{~F}_{0.50}: 25 \%$ irrigation and 50\% (50:50:50 NPK) fertigation application, $\mathrm{T}_{5} \mathrm{~F}_{0.50}: 0 \%$ irrigation and 50\% (50:50:50 NPK) fertigation.

Drip irrigation method was used in the trial. Irrigation water amount was calculated by placing flow measurement devices per parcel. The need for watering of the cabbage is provided by a deep well $\left(31 \mathrm{~s}^{-1}\right)$ located in the greenhouse area. The depth of the well is 18 meters. Chemical composition of irrigation water was presented in Table- 2 . Groundwater composition of Yenişehir area is generally alkaline. The irrigation water applied in the experimental research was analysed and was determined to be in the $\mathrm{C}_{2} \mathrm{~S}_{1}$ class with low sodium risk and medium EC value. The water of the $\mathrm{C}_{2} \mathrm{~S}_{1}$ quality class has low sodium risk and medium electrical conductivity (EC). The irrigation of water of this quality class is used for plants with medium and highly salinity resistant. In addition, $\mathrm{C}_{1} \mathrm{~S}_{1}$ quality class water can be used in all plants and soils without creating a risk of alkalinity. $\mathrm{C}_{2} \mathrm{~S}_{1}$ quality class water was applied in a study on cabbage plants (Ashraf and Ewees, 2008).

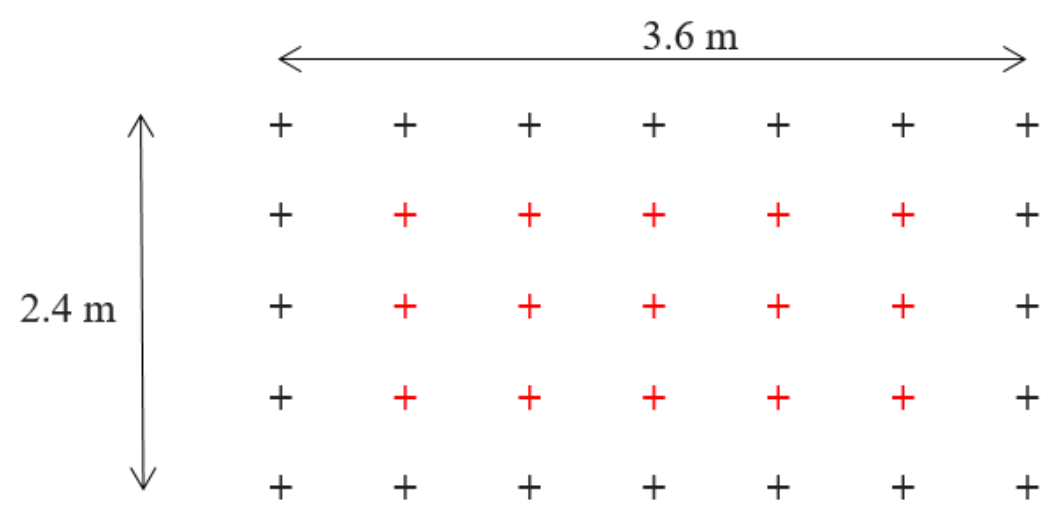

Figure 5. The detail of a plot
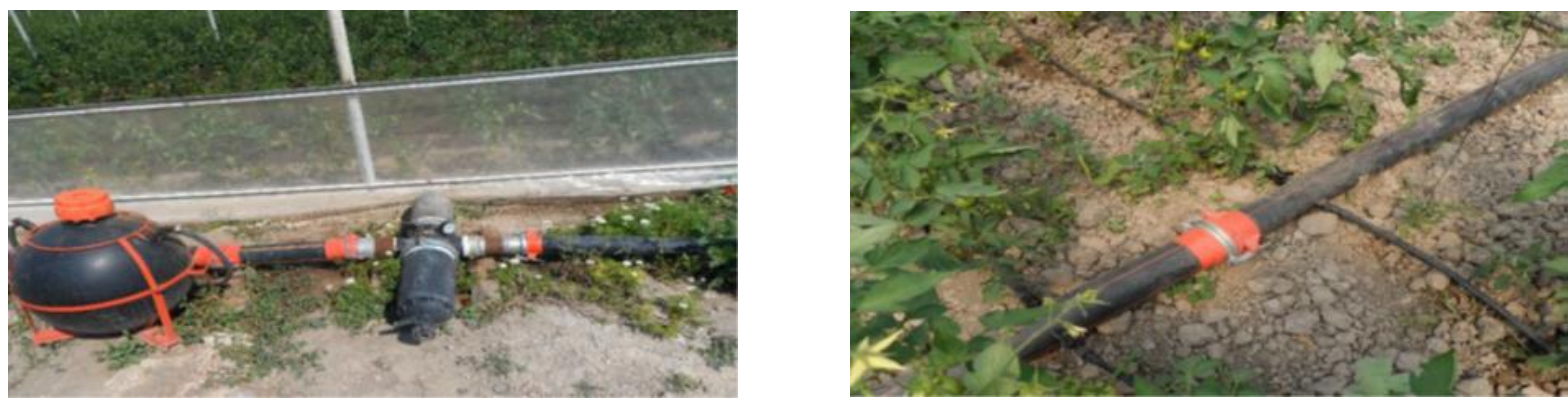

Figure 6. (a) Drip irrigation system, (b) Main and lateral pipes

Table 2. Specific properties of irrigation water

\begin{tabular}{c|cccccccc}
\hline \multirow{2}{*}{$\begin{array}{c}\text { Water } \\
\text { source }\end{array}$} & \multirow{2}{*}{$\mathrm{EC}_{25} \times\left(10^{6}\right)$} & $\mathrm{Na}^{+}$ & $\mathrm{K}^{+}$ & $\mathrm{Ca}^{2+}$ & $\mathrm{Mg}^{2+}$ & \multirow{2}{*}{$\mathrm{pH}$} & \multirow{2}{*}{ Class } & \multirow{2}{*}{$\mathrm{SAR}$} \\
\cline { 2 - 5 } & & \multicolumn{2}{c}{$\left(\mathrm{me} \mathrm{L}^{-1}\right)$} & & & & \\
\hline Deep well & 723 & 2.5 & 2.67 & 9.55 & 5.8 & 7.17 & $\mathrm{C}_{2} \mathrm{~S}_{1}$ & 0.85 \\
\hline
\end{tabular}


Soil moisture between $30-120 \mathrm{~cm}$ before and after irrigation was monitored by gravimetric method. Evapotranspiration (ET) was calculated by means of the water balance equation (Eq. 1).

$$
\mathrm{ET}=\mathrm{I}+\mathrm{P}-\mathrm{Rf}-\mathrm{Dp} \pm \Delta \mathrm{S}
$$

In the water balance equation, ET, I, P, Rf, Df and $\Delta \mathrm{S}$ symbols symbolize plant water consumption, effective irrigation water, total precipitation, surface flow $(\mathrm{mm})$, the infiltrating water under the root zone $(\mathrm{mm})$, the amount of change in storage $(\mathrm{mm} / 120 \mathrm{~cm})$, respectively. Irrigation water was applied to the crop by the drip irrigation method before planting seedlings. Total precipitation $(\mathrm{P})$ and surface flow (Rf) were neglected in water requirements and consumption calculations in greenhouse. Soil water values in soil profiles deeper than $120 \mathrm{~cm}$ were accepted as deep drainage (Dp) and these values were neglected. The amount of fertilizer to be applied to each unit area was determined and calculated in $\mathrm{kg} / \mathrm{ha}$ by the equation as follows (İşcan et al., 2002) (Eq. 2):

$$
\mathrm{FW}=\frac{\mathrm{Fr} \cdot 100}{\mathrm{Cn}}
$$

In equality; Fw, Fr and $\mathrm{Cn}$ symbolize fertilizer weight (kg/ha), nutrient amount (kg/ha) and nutrient density contained in the fertilizer, (respectively Eq. 2). Similarly, the fertilizer valume to be applied to each unit area was given in the third equation (İşcan et al., 2002) (Eq. 3):

$$
\mathrm{Fv}=\frac{\mathrm{F}_{\mathrm{w}}}{\mathrm{S}_{\mathrm{w}}}
$$

In equality; Fv, Fw and $\mathrm{Sw}$ symbolize the volume of fertilizer (1/ha), fertilizer weight $(\mathrm{kg} / \mathrm{ha})$ and unit weight of the fertilizer, (respectively Eq. 3). The application time chemical fertilizer to be given with water per unit area ( $\mathrm{kg} / \mathrm{ha}$ or $1 / \mathrm{ha}$ ) was calculated with the fourth equation (Eq. 4) given below (İşcan et al., 2002):

$$
\mathrm{T}=\frac{\mathrm{V}_{\mathrm{W}}}{\mathrm{Q}_{\mathrm{t}}}
$$

In equality; T, Vw and Qt symbolize the application time of chemical fertilizer (h), the amount of water (l/ha) and the flow rate of the fertilization tank, (respectively (Eq. 4). Steward Model (Eq.5) helps to describe the relationship between yield and ET in this experimental research (Stewart et al., 1975; Doorenbos and Kassam, 1979). The equation can be given as:

$$
\left(1-\frac{Y a}{Y m}\right)=k y\left(1-\frac{E T a}{E T m}\right)
$$

In the Steward Equation, Ym (t ha-1) and Ya (t ha-1) symbols symbolize the highest and actual yields, respectively, while ETm $(\mathrm{mm})$ and ETa $(\mathrm{mm})$ symbols symbolize the highest and actual evapotranspiration, respectively. Irrigation efficiency was determined by the WUE value, while the symbol ky was defined as the yield response factor. WUE and IWUE are expressed as two terms that show how efficiently irrigation water is used during the production periods of the plant (Bos, 1980). WUE value was calculated by dividing the economic yield by the seasonal evapotranspiration (Eq.6):

$$
\mathrm{WUE}=\frac{\mathrm{E}_{\mathrm{y}}}{\mathrm{ET}}
$$

In the equation, Ey and ET values show the economic yield ( $\mathrm{t}$ ha-1) and seasonal evapotranspiration ( $\mathrm{mm}$ ), respectively. IWUE value was calculated by dividing the economic efficiency by the amount of irrigation water (Zhang et al., 1999) (Eq. 7):

$$
\operatorname{IWUE}=\left(\frac{\mathrm{E}_{\mathrm{y}}}{\mathrm{I}}\right)
$$

In the equation, Ey and I values show the economic yield $\left(\mathrm{t} \mathrm{ha}^{-1}\right)$ and the amount of the irrigation water $(\mathrm{mm})$, respectively. Before the seedlings were plant into the greenhouse soil, the water content of the soil up $120 \mathrm{~cm}$ depth was calculated. Moisture level of the soil was completed to the level of field capacity in all treatments before starting irrigation. Irrigation was begun on June 08 in 2014 and in 2015 and it was repeated every 7 days.

Cabbages were harvested 90 days after planting in the greenhouse. Considering the season, the development period of the cabbage in the greenhouse should have been shorter. This situations can be attributed to the fatigue of the greenhouse soil. The variance analysis of the yield and quality parameters of cabbage was evaluated by LSD multiple comparison test $(\mathrm{P}<0.05)$. Using MSTAT-C and MINITAB software, yield productivity and quality parameters values were analysed (Steel and Torrie, 1980).

\section{Results}

Before planting, each plot was given irrigation water to bring the soil moisture level up to field capacity (that is, 0$60 \mathrm{~cm}$ soil depth moisture level). After a week from planting cabbage seedlings, the first irrigation water treatment was applied. The maximum and minimum irrigation water amounts for 2014 and 2015 years were obtained from $\mathrm{T}_{1} \mathrm{~F}_{1.0}-\mathrm{T}_{1} \mathrm{~F}_{0.5}$ and $\mathrm{T}_{5} \mathrm{~F}_{1.0}-\mathrm{T}_{5} \mathrm{~F}_{0.5}$ treatments were $620-0,600-0 \mathrm{~mm}$ and $660-0,600-0 \mathrm{~mm}$, respectively. The actual evapotranspiration values for $\mathrm{T}_{1} \mathrm{~F}_{1.0}-\mathrm{T}_{1} \mathrm{~F}_{0.5}$ and $\mathrm{T}_{5} \mathrm{~F}_{1.0}-\mathrm{T}_{5} \mathrm{~F}_{05}$ treatments in the first year varied between $665-700 \mathrm{~mm}$ and $200-150 \mathrm{~mm}$, respectively. These values in the second year varied between $680-710 \mathrm{~mm}$ and 225 $180 \mathrm{~mm}$, respectively (Table 3, Table 4, Table 5).

The highest head yield values in treatments which is applied as 100\% (100:100:100 NPK) and 50\% (50:50:50 NPK) of fertigation for the 2014-2015 years were obtained from $\mathrm{T}_{1} \mathrm{~F}_{1.0}$ and $\mathrm{T}_{1} \mathrm{~F}_{0.5}$ treatments and found as 73.2-70.6 $\mathrm{t}$ $\mathrm{ha}^{-1}$ and 68.4-66.8 $\mathrm{t} \mathrm{ha}^{-1}$, respectively. As expected, minimum yield values for 2014 and 2015 years were found from control $\mathrm{T}_{5} \mathrm{~F}_{1.0}$ and $\mathrm{T}_{5} \mathrm{~F}_{0.5}$ treatments $(5.0-3.0$ and 3.3 $\left.-3.0 \mathrm{t} \mathrm{ha}^{-1}\right)$, in which irrigation was not applied. The relationship between irrigation water (IW) with yield (Ya) and the relationship between ETc with yield (Ya) for 2014 and 2015 years were as shown in Figure 7 and 8. During the 2014 and 2015 study years, the product yield of the untreated $\mathrm{T}_{5} \mathrm{~F}_{1.0}$ and $\mathrm{T}_{5} \mathrm{~F}_{0.5}$ treatments were lower by 1364.0-2253.0 \% and 1972.7-2126.7\% compared to the $\mathrm{T}_{1} \mathrm{~F}_{1.0}$ and $\mathrm{T}_{1} \mathrm{~F}_{0.5}$ treatments (Table 6 and 7 ). Head yield and quality have been reduced due to water shortages.

In the first year of the study, head yield, head diameter, head height and head weight for two different fertigation levels were affected by deficit irrigation. 
Table 3. Applied water and ET values according to irrigation and fertigation treatments in 2014 and 2015 years

\begin{tabular}{|c|c|c|c|c|c|}
\hline Fertilization & IT & AW 2014 & AW 2015 & CE 2014 & CE 2015 \\
\hline \multirow{5}{*}{$\begin{array}{l}\text { 100\% Fertilization1 } \\
\left(\mathrm{F}_{1.0}: 100 \% 100: 100: 100 \mathrm{NPK}\right)\end{array}$} & $\mathrm{T}_{1} \mathrm{~F}_{1.0}$ & 620.0 & 660.0 & 665.0 & 680.0 \\
\hline & $\mathrm{T}_{2} \mathrm{~F}_{1.0}$ & 465.0 & 495.0 & 500.0 & 505.0 \\
\hline & $\mathrm{T}_{3} \mathrm{~F}_{1.0}$ & 310.0 & 330.0 & 350.0 & 380.0 \\
\hline & $\mathrm{T}_{4} \mathrm{~F}_{1.0}$ & 155.0 & 165.0 & 280.0 & 300.0 \\
\hline & $\mathrm{T}_{5} \mathrm{~F}_{1.0}$ & 0.0 & 0.0 & 200.0 & 225.0 \\
\hline \multirow{5}{*}{$\begin{array}{l}\text { 50\% Fertilization } \\
\text { (F0.5: 50\% 50:50:50 NPK) }\end{array}$} & $\mathrm{T}_{1} \mathrm{~F}_{0.5}$ & 600.0 & 660.0 & 700.0 & 710.0 \\
\hline & $\mathrm{T}_{2} \mathrm{~F}_{0.5}$ & 450.0 & 495.0 & 550.0 & 530.0 \\
\hline & $\mathrm{T}_{3} \mathrm{~F}_{0.5}$ & 300.0 & 330.0 & 400.0 & 400.0 \\
\hline & $\mathrm{T}_{4} \mathrm{~F}_{0.5}$ & 150.0 & 165.0 & 240.0 & 260.0 \\
\hline & $\mathrm{T}_{5} \mathrm{~F}_{0.5}$ & 0.0 & 0.0 & 150.0 & 180.0 \\
\hline
\end{tabular}

Table 4. Relationship between yield and yield response factor ( $k y)$ with the decrease in water use, for cabbage in 2014 year

\begin{tabular}{|c|c|c|c|c|c|c|c|c|}
\hline & Yield $\left(\mathrm{t} \mathrm{ha}^{-1}\right)$ & Applied Water (mm) & $\mathrm{ETa}(\mathrm{mm})$ & $\mathrm{ETa} / \mathrm{ETm}$ & $\mathrm{Ya} / \mathrm{Ym}$ & 1-(ETa/ETm) & 1-(Ya/Ym) & ky \\
\hline $\mathrm{T}_{1} \mathrm{~F}_{1.0}$ & 73.2 & 620.0 & 665.0 & 1.000 & 1.000 & 0.000 & 0.000 & 0.000 \\
\hline $\mathrm{T}_{2} \mathrm{~F}_{1.0}$ & 55.0 & 465.0 & 500.0 & 0.752 & 0.751 & 0.248 & 0.249 & 1.002 \\
\hline $\mathrm{T}_{3} \mathrm{~F}_{1.0}$ & 35.8 & 310.0 & 350.0 & 0.526 & 0.489 & 0.474 & 0.511 & 1.079 \\
\hline $\mathrm{T}_{4} \mathrm{~F}_{1.0}$ & 16.0 & 155.0 & 280.0 & 0.421 & 0.219 & 0.579 & 0.781 & 1.350 \\
\hline $\mathrm{T}_{5} \mathrm{~F}_{1.0}$ & 5.0 & 0.0 & 200.0 & 0.301 & 0.068 & 0.699 & 0.932 & 1.332 \\
\hline $\mathrm{T}_{1} \mathrm{~F}_{0.5}$ & 70.6 & 600.0 & 700.0 & 1.000 & 1.000 & 0.000 & 0.000 & 0.000 \\
\hline $\mathrm{T}_{2} \mathrm{~F}_{0.5}$ & 53.1 & 450.0 & 550.0 & 0.786 & 0.752 & 0.214 & 0.248 & 1.157 \\
\hline $\mathrm{T}_{3} \mathrm{~F}_{0.5}$ & 34.0 & 300.0 & 400.0 & 0.571 & 0.482 & 0.429 & 0.518 & 1.210 \\
\hline $\mathrm{T}_{4} \mathrm{~F}_{0.5}$ & 14.0 & 150.0 & 240.0 & 0.343 & 0.198 & 0.657 & 0.802 & 1.220 \\
\hline $\mathrm{T}_{5} \mathrm{~F}_{0.5}$ & 3.0 & 0.0 & 150.0 & 0.214 & 0.042 & 0.786 & 0.958 & 1.219 \\
\hline
\end{tabular}

Table 5. Relationship between yield and yield response factor (ky) with the decrease in water use, for cabbage in 2015 year.

\begin{tabular}{l|cccccccc}
\hline & Yield $\left(\mathrm{t} \mathrm{ha}^{-1}\right)$ & Applied Water $(\mathrm{mm})$ & $\mathrm{ETa}(\mathrm{mm})$ & $\mathrm{ETa} / \mathrm{ETm}$ & $\mathrm{Ya} / \mathrm{Ym}$ & $1-(\mathrm{ETa} / \mathrm{ETm})$ & $1-(\mathrm{Ya} / \mathrm{Ym})$ & $\mathrm{ky}$ \\
\hline $\mathrm{T}_{3} \mathrm{~F}_{1.0}$ & 34.0 & 330.0 & 380.0 & 0.559 & 0.497 & 0.441 & 0.503 & 1.140 \\
$\mathrm{~T}_{4} \mathrm{~F}_{1.0}$ & 15.8 & 165.0 & 300.0 & 0.441 & 0.231 & 0.559 & 0.769 & 1.376 \\
$\mathrm{~T}_{5} \mathrm{~F}_{1.0}$ & 3.3 & 0.0 & 225.0 & 0.331 & 0.048 & 0.669 & 0.952 & 1.422 \\
$\mathrm{~T}_{1} \mathrm{~F}_{0.5}$ & 66.8 & 600.0 & 710.0 & 1.000 & 1.000 & 0.000 & 0.000 & 0.000 \\
$\mathrm{~T}_{2} \mathrm{~F}_{0.5}$ & 50.0 & 450.0 & 530.0 & 0.746 & 0.749 & 0.254 & 0.251 & 0.992 \\
$\mathrm{~T}_{3} \mathrm{~F}_{0.5}$ & 32.4 & 300.0 & 400.0 & 0.563 & 0.485 & 0.437 & 0.515 & 1.179 \\
$\mathrm{~T}_{4} \mathrm{~F}_{0.5}$ & 13.7 & 150.0 & 260.0 & 0.366 & 0.205 & 0.634 & 0.795 & 1.254 \\
$\mathrm{~T}_{5} \mathrm{~F}_{0.5}$ & 3.0 & 0.0 & 180.0 & 0.254 & 0.045 & 0.746 & 0.955 & 1.279 \\
\hline
\end{tabular}
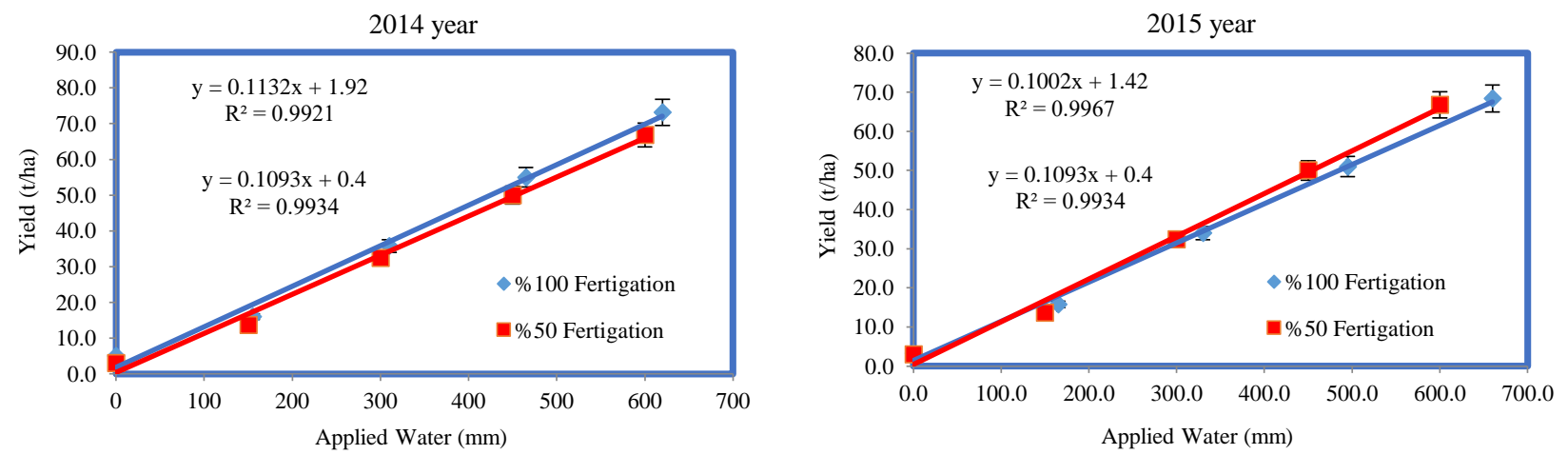

Figure 7. The relationship between irrigation water (IW) with (yield Ya) for 2014 and 2015 years. (The error bars are SE of 15 plants)
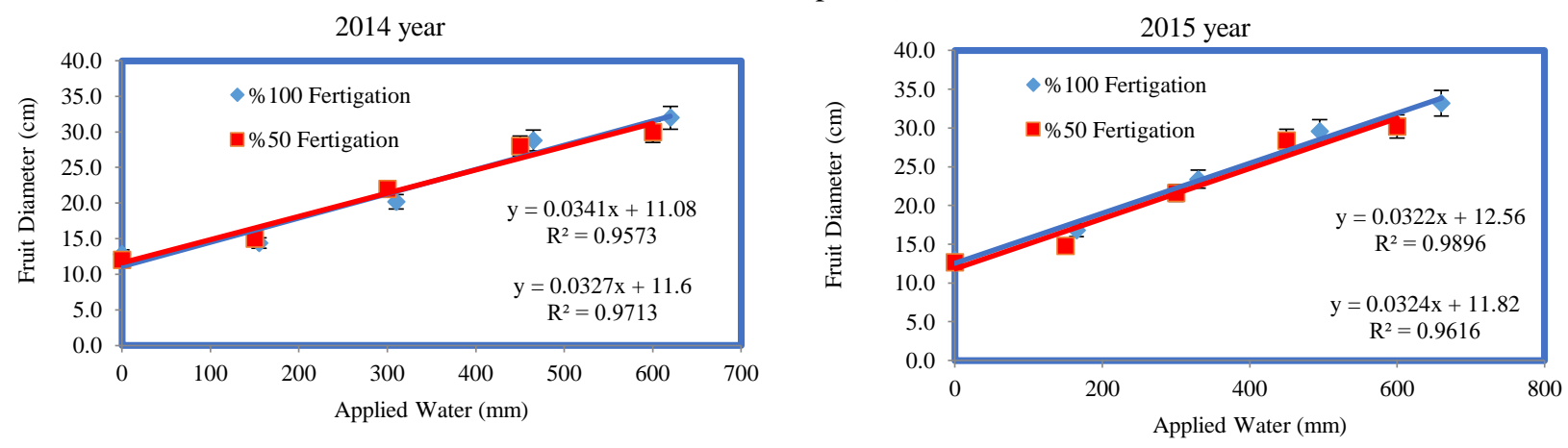

Figure 8. The relationship between ETc with yield (Ya) for 2014 and 2015 years. (The errors bars are SE of 15 plants) 
Table 6. Effects of irrigation treatments on yield and quality parameters of cabbage in 2014 year.

\begin{tabular}{|c|c|c|c|c|c|c|}
\hline $\begin{array}{c}\text { Fertilization } \\
\text { Treatments }\end{array}$ & $\begin{array}{l}\text { Fertigation } \\
\text { Treatments }\end{array}$ & $\begin{array}{l}\text { Head Yield } \\
\qquad\left(\mathrm{t} \mathrm{ha}^{-1}\right)\end{array}$ & $\begin{array}{c}\text { Head } \\
\text { Diameter }(\mathrm{cm})\end{array}$ & $\begin{array}{l}\text { Head Height } \\
\text { (cm) }\end{array}$ & $\begin{array}{c}\text { Head } \\
\text { Weight }(\mathrm{kg})\end{array}$ & $\begin{array}{c}\text { Dry Matter } \\
\text { Ratio }(\%)\end{array}$ \\
\hline \multirow{5}{*}{$\begin{array}{l}\text { 100\% Fertilization } \\
\text { (F1.0: } 100 \%)\end{array}$} & $\mathrm{T}_{1} \mathrm{~F}_{1.0}$ & $73.2^{\mathrm{a}}$ & $32.0^{\mathrm{a}}$ & $30.8^{\mathrm{a}}$ & $6.2^{\mathrm{a}}$ & $5.7^{\mathrm{e}}$ \\
\hline & $\mathrm{T}_{2} \mathrm{~F}_{1.0}$ & $55.0^{\mathrm{b}}$ & $28.8^{\mathrm{bc}}$ & $28.0^{\mathrm{b}}$ & $5.8^{\mathrm{ab}}$ & $6.5^{\mathrm{d}}$ \\
\hline & $\mathrm{T}_{3} \mathrm{~F}_{1.0}$ & $35.8^{\mathrm{c}}$ & $20.2^{\mathrm{e}}$ & $24.0 \mathrm{~d}$ & $5.0^{\mathrm{cd}}$ & $8.5^{\mathrm{c}}$ \\
\hline & $\mathrm{T}_{4} \mathrm{~F}_{1.0}$ & $16.0^{\mathrm{d}}$ & $14.4^{\mathrm{f}}$ & $18.2^{\mathrm{f}}$ & $3.5^{\mathrm{e}}$ & $11.0^{\mathrm{ab}}$ \\
\hline & $\mathrm{T}_{5} \mathrm{~F}_{1.0}$ & $5.0^{\mathrm{e}}$ & $12.8^{\mathrm{g}}$ & $15.0^{\mathrm{g}}$ & $2.2^{\mathrm{f}}$ & $11.5^{\mathrm{a}}$ \\
\hline \multirow{2}{*}{$\begin{array}{l}\text { Treatments } \\
\text { Blocks }\end{array}$} & & $* *$ & $* *$ & $* *$ & $* *$ & $* *$ \\
\hline & & ns & ns & ns & ns & $\mathrm{ns}$ \\
\hline \multirow{5}{*}{$\begin{array}{l}50 \% \text { Fertilization } \\
(\mathrm{F} 0.5: \% 50)\end{array}$} & $\mathrm{T}_{1} \mathrm{~F}_{0.5}$ & $70.6^{a}$ & $30.0^{\mathrm{b}}$ & $30.5^{\mathrm{a}}$ & $5.9^{\mathrm{ab}}$ & $5.5^{\mathrm{e}}$ \\
\hline & $\mathrm{T}_{2} \mathrm{~F}_{0.5}$ & $53.1^{\mathrm{b}}$ & $28.0^{\mathrm{c}}$ & $27.0^{c}$ & $5.5^{\mathrm{bc}}$ & $6.6^{\mathrm{d}}$ \\
\hline & $\mathrm{T}_{3} \mathrm{~F}_{0.5}$ & $34.0^{\mathrm{c}}$ & $22.0^{\mathrm{d}}$ & $22.4^{\mathrm{e}}$ & $4.5^{\mathrm{d}}$ & $8.3^{c}$ \\
\hline & $\mathrm{T}_{4} \mathrm{~F}_{0.5}$ & $14.0^{\mathrm{d}}$ & $15.0^{f}$ & $15.3^{\mathrm{g}}$ & $3.0^{\mathrm{e}}$ & $10.7^{\mathrm{b}}$ \\
\hline & $\mathrm{T}_{5} \mathrm{~F}_{0.5}$ & $3.0^{\mathrm{e}}$ & $12.0^{\mathrm{g}}$ & $14.0^{\mathrm{h}}$ & $2.0^{\mathrm{f}}$ & $11.2^{\mathrm{ab}}$ \\
\hline Treatments & & $* *$ & $* *$ & $* *$ & $* *$ & $* *$ \\
\hline Blocks & & $\mathrm{ns}$ & ns & ns & ns & ns \\
\hline
\end{tabular}

Table 7. Effects of irrigation treatments on yield and quality parameters of cabbage in 2015 year.

\begin{tabular}{|c|c|c|c|c|c|c|}
\hline $\begin{array}{c}\text { Fertilization } \\
\text { Treatments }\end{array}$ & $\begin{array}{l}\text { Fertigation } \\
\text { Treatments }\end{array}$ & $\begin{array}{l}\text { Head Yield } \\
\left(\mathrm{t} \mathrm{ha}^{-1}\right)\end{array}$ & $\begin{array}{c}\text { Head } \\
\text { Diameter }(\mathrm{cm})\end{array}$ & $\begin{array}{l}\text { Head Height } \\
(\mathrm{cm})\end{array}$ & $\begin{array}{c}\text { Head } \\
\text { Weight }(\mathrm{kg})\end{array}$ & $\begin{array}{l}\text { Dry Matter } \\
\text { Ratio }(\%)\end{array}$ \\
\hline \multirow{5}{*}{$\begin{array}{l}\text { 100\% Fertilization } \\
(\mathrm{F} 1.0: 100 \%)\end{array}$} & $\mathrm{T}_{1} \mathrm{~F}_{1.0}$ & $68.4^{\mathrm{a}}$ & $33.2^{\mathrm{a}}$ & $31.6^{\mathrm{a}}$ & $6.0^{\mathrm{a}}$ & $6.2^{\mathrm{g}}$ \\
\hline & $\mathrm{T}_{2} \mathrm{~F}_{1.0}$ & $51.0^{\mathrm{b}}$ & $29.6^{\mathrm{b}}$ & $28.8^{c}$ & $5.7^{\mathrm{a}}$ & $7.0^{\mathrm{f}}$ \\
\hline & $\mathrm{T}_{3} \mathrm{~F}_{1.0}$ & $34.0^{\mathrm{c}}$ & $23.4^{\mathrm{d}}$ & $25.0^{\mathrm{d}}$ & $4.9^{\mathrm{bc}}$ & $8.5^{\mathrm{d}}$ \\
\hline & $\mathrm{T}_{4} \mathrm{~F}_{1.0}$ & $15.8^{\mathrm{d}}$ & $16.8^{f}$ & $20.2^{\mathrm{e}}$ & $3.4^{\mathrm{d}}$ & $10.8^{c}$ \\
\hline & $\mathrm{T}_{5} \mathrm{~F}_{1.0}$ & $3.3^{\mathrm{e}}$ & $13.0^{\mathrm{h}}$ & $15.4^{\mathrm{f}}$ & $2.4^{\mathrm{e}}$ & $11.3^{\mathrm{ab}}$ \\
\hline \multirow{2}{*}{$\begin{array}{l}\text { Treatments } \\
\text { Blocks }\end{array}$} & & $* *$ & $* *$ & $* *$ & $* *$ & $* *$ \\
\hline & & $\mathrm{ns}$ & ns & $\mathrm{ns}$ & ns & ns \\
\hline \multirow{5}{*}{$\begin{array}{l}50 \% \text { Fertilization } \\
(\mathrm{F} 0.5: \% 50)\end{array}$} & $\mathrm{T}_{1} \mathrm{~F}_{0.5}$ & $66.8^{a}$ & $30.2^{\mathrm{b}}$ & $30.2^{b}$ & $5.8^{\mathrm{a}}$ & $6.8^{f}$ \\
\hline & $\mathrm{T}_{2} \mathrm{~F}_{0.5}$ & $50.0^{\mathrm{b}}$ & $28.4^{\mathrm{c}}$ & $28.4^{\mathrm{c}}$ & $5.4^{\mathrm{ab}}$ & $7.5^{\mathrm{e}}$ \\
\hline & $\mathrm{T}_{3} \mathrm{~F}_{0.5}$ & $32.4^{\mathrm{c}}$ & $21.6^{\mathrm{e}}$ & $24.5^{\mathrm{d}}$ & $4.6^{c}$ & $8.8^{\mathrm{d}}$ \\
\hline & $\mathrm{T}_{4} \mathrm{~F}_{0.5}$ & $13.7^{\mathrm{d}}$ & $14.8^{g}$ & $20.8^{\mathrm{e}}$ & $3.2^{\mathrm{d}}$ & $11.0^{\mathrm{bc}}$ \\
\hline & $\mathrm{T}_{5} \mathrm{~F}_{0.5}$ & $3.0^{\mathrm{e}}$ & $12.7^{\mathrm{h}}$ & $15.8^{f}$ & $2.2^{\mathrm{e}}$ & $11.5^{\mathrm{a}}$ \\
\hline \multirow{2}{*}{$\begin{array}{l}\text { Treatments } \\
\text { Blocks }\end{array}$} & & $* *$ & $* *$ & $* *$ & $* *$ & $* *$ \\
\hline & & ns & ns & ns & ns & ns \\
\hline
\end{tabular}

The mean yield values obtained from $\mathrm{T}_{1} \mathrm{~F}_{1.0}, \mathrm{~T}_{2} \mathrm{~F}_{1.0}$, $\mathrm{T}_{3} \mathrm{~F}_{1.0}, \mathrm{~T}_{4} \mathrm{~F}_{1.0}, \mathrm{~T}_{5} \mathrm{~F}_{1.0}$ and $\mathrm{T}_{1} \mathrm{~F}_{0.5}, \mathrm{~T}_{2} \mathrm{~F}_{0.5}, \mathrm{~T}_{3} \mathrm{~F}_{0.5}, \mathrm{~T}_{4} \mathrm{~F}_{0.5}, \mathrm{~T}_{5} \mathrm{~F}_{0.5}$ treatments were almost all in a different statistical group. Fruit diameter, fruit height and fruit weight values were affected by too much deficit irrigation. All values of head height every two years were situated in a different statistical group. Therefore, head height values in 2014 and 2015 years also differed statistically. In the second year, all the head yield values obtained from the treatments were found in a different statistical group while head weight values in $\mathrm{T}_{1} \mathrm{~F}_{1.0}$ and $\mathrm{T}_{2} \mathrm{~F}_{1.0}$ treatments were in the same statistical group. Head diameter values were affected by deficit irrigation and each of the treatments were situated in a different statistical group. While there was a high linear relationship between the amount of applied water (IW) and head diameter, head height and head weight, there was a negative linear relationship between dry matter and IW. The amount of dry matter decreases as the water content in the head yield increases. The related equations for $\mathrm{F}_{1.0}$ : $100 \% \quad(100: 100: 100 \mathrm{NPK})$ and $\mathrm{F}_{0.5}: 50 \%$ (100:100:100 NPK) fertigation treatments for 2014 and 2015 years were given in Figure 9.

\section{Crop Yield Response Factor (ky)}

Yield response factor $(\mathrm{ky})$ is a proportional value, and it states the sensitive of the plant production against water deficiency (Stewart, 1975, Doorenbos and Kassam, 1979). ky in different fertigation levels $\left(\mathrm{F}_{1.0}: \% 100\right.$ and $\mathrm{F}_{0.5}: \% 50$ fertigation levels) for the 2014 and 2015 experimental years was calculated as 1.20-1.19 and 1.23-1.18, respectively (Figure 10). Except $\mathrm{T}_{5} \mathrm{~F}_{1.0}$ and $\mathrm{T}_{5} \mathrm{~F}_{0.5}$ treatments, ky values increased parallel to the increase of water amount.

\section{Water-Use Efficiency}

During the trial years, when the irrigation water amount decreased, the WUE and IWUE values also decreased. The highest WUE values of both years were obtained from $\mathrm{T}_{1} \mathrm{~F}_{1.0}, \mathrm{~T}_{2} \mathrm{~F}_{1.0}$ and $\mathrm{T}_{1} \mathrm{~F}_{0.5}, \mathrm{~T}_{2} \mathrm{~F}_{0.5}$ treatments and were calculated as $0.110,0.110-0.101,0.097 \mathrm{~kg} \mathrm{~m}^{-3}$ and 0.101 , $0.101-0.094,0.094 \mathrm{~kg} \mathrm{~m}^{-3}$, respectively. The highest IWUE values of both years were similarly obtained from $\mathrm{T}_{1} \mathrm{~F}_{1.0}, \mathrm{~T}_{2} \mathrm{~F}_{1.0}$ and $\mathrm{T}_{1} \mathrm{~F}_{0.5}, \mathrm{~T}_{2} \mathrm{~F}_{0.5}$ treatments and were calculated as $0.118,0.118-0.118,0.118 \mathrm{~kg} \mathrm{~m}^{-3}$ and 0.104 , $0,103-0,111,0.111 \mathrm{~kg} \mathrm{~m}^{-3}$, respectively. The WUE and IWUE values of $\mathrm{T}_{1} \mathrm{~F}_{1.0}$ and $\mathrm{T}_{2} \mathrm{~F}_{1.0}$ treatments in 2014 were found to be higher than the other treatments such as $\mathrm{T}_{3} \mathrm{~F}_{1.0}$, $\mathrm{T}_{4} \mathrm{~F}_{1.0}, \mathrm{~T}_{5} \mathrm{~F}_{1.0}$ and $\mathrm{T}_{3} \mathrm{~F}_{0.50}, \mathrm{~T}_{4} \mathrm{~F}_{0.5}, \mathrm{~T}_{5} \mathrm{~F}_{0.5}$ respectively. The WUE and IWUE values of $\mathrm{T}_{1} \mathrm{~F}_{1.0}, \mathrm{~T}_{2} \mathrm{~F}_{1.0}, \mathrm{~T}_{1} \mathrm{~F}_{0.50}, \mathrm{~T}_{2} \mathrm{~F}_{0.5}$, treatments in 2014 and 2015 years were found to be higher than the other treatments such as $\mathrm{T}_{3} \mathrm{~F}_{1.0}, \mathrm{~T}_{4} \mathrm{~F}_{1.0}, \mathrm{~T}_{5} \mathrm{~F}_{1.0}$ and $\mathrm{T}_{3} \mathrm{~F}_{0.5}, \mathrm{~T}_{4} \mathrm{~F}_{0.5}, \mathrm{~T}_{5} \mathrm{~F}_{0.5}$ respectively (Table 8 and 9 ). 

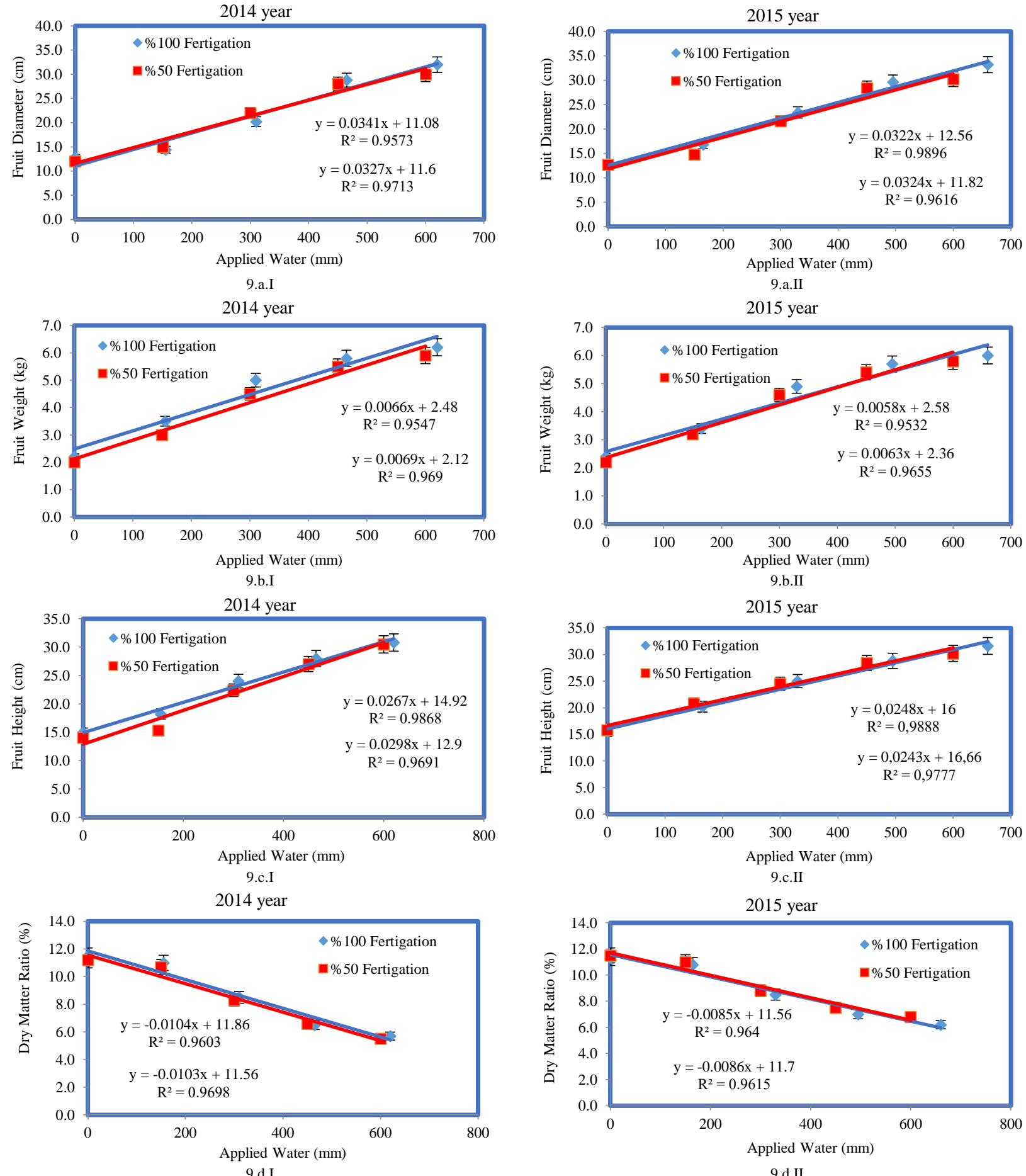

Figure 9. Relationship between applied of irrigation water and head diameter (a.I-a.II), head weight (b.I-b.II), head height (c.I-c.II) and dry matter ratio (d.I-d.II).
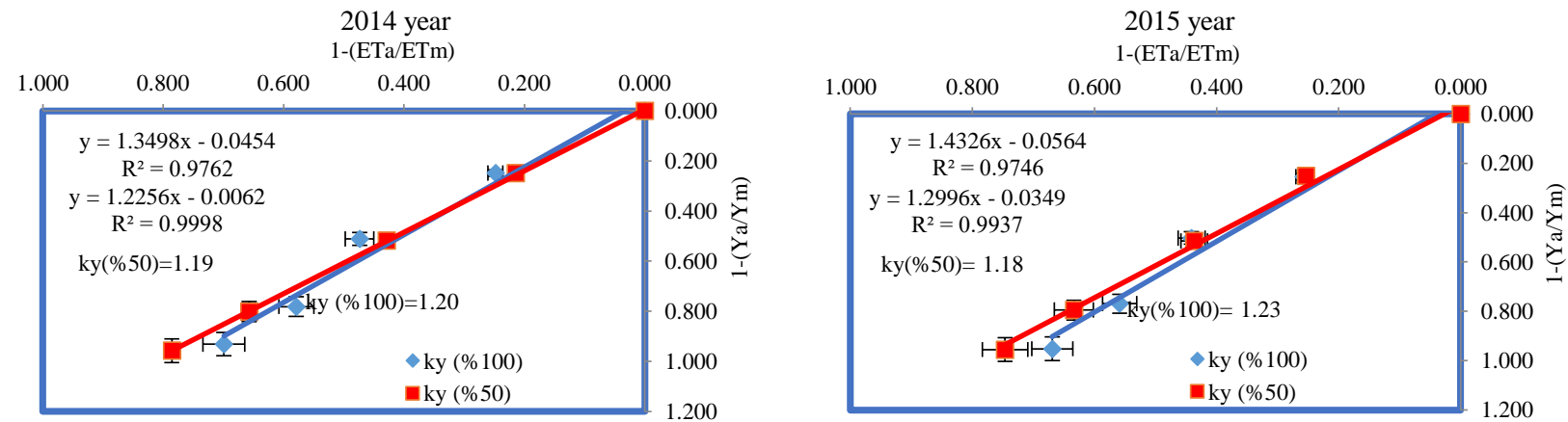

Figure 10. The relationship between relative yield decrease and relative evapotranspiration deficit for the experimental years (2014 and 2015) 
Table 8. WUE and IWUE values for drip-irrigated cabbage at different irrigation treatments for 2014 year.

\begin{tabular}{l|ccccc}
\hline Fertigation Treatments & Yield $\left(\mathrm{t} \mathrm{ha}^{-1}\right)$ & Applied Water $(\mathrm{mm})$ & ETa $(\mathrm{mm})$ & WUE $\left(\mathrm{kg} \mathrm{m}^{-3}\right)$ & IWUE $\left(\mathrm{kg} \mathrm{m}^{-3}\right)$ \\
\hline T1F1.0 & 73.2 & 620.0 & 665.0 & 0.110 & 0.118 \\
T2F1.0 & 55.0 & 465.0 & 500.0 & 0.110 & 0.118 \\
T3F1.0 & 35.8 & 310.0 & 350.0 & 0.102 & 0.115 \\
T4F1.0 & 16.0 & 155.0 & 280.0 & 0.057 & 0.103 \\
T5F1.0 & 5.0 & 0.0 & 200.0 & 0.025 & 0.000 \\
T1F0.5 & 70.6 & 600.0 & 700.0 & 0.101 & 0.118 \\
T2F0.5 & 53.1 & 450.0 & 550.0 & 0.097 & 0.118 \\
T3F0.5 & 34.0 & 300.0 & 400.0 & 0.085 & 0.113 \\
T4F0.5 & 14.0 & 150.0 & 240.0 & 0.058 & 0.093 \\
T5F0.5 & 3.0 & 0.0 & 150.0 & 0.020 & 0.000 \\
\hline
\end{tabular}

Table 9. WUE and IWUE values for drip-irrigated cabbage at different irrigation treatments for 2015 year.

\begin{tabular}{l|ccccc}
\hline Fertigation Treatments & Yield $\left(\mathrm{t} \mathrm{ha}^{-1}\right)$ & Applied Water $(\mathrm{mm})$ & ETa $(\mathrm{mm})$ & WUE $\left(\mathrm{kg} \mathrm{m}^{-3}\right)$ & IWUE $\left(\mathrm{kg} \mathrm{m}^{-3}\right)$ \\
\hline T1F1.0 & 68.4 & 660.0 & 680.0 & 0.101 & 0.104 \\
T2F1.0 & 51.0 & 495.0 & 505.0 & 0.101 & 0.103 \\
T3F1.0 & 34.0 & 330.0 & 380.0 & 0.089 & 0.103 \\
T4F1.0 & 15.8 & 165.0 & 300.0 & 0.053 & 0.096 \\
T5F1.0 & 3.3 & 0.0 & 225.0 & 0.015 & 0.000 \\
T1F0.5 & 66.8 & 600.0 & 710.0 & 0.094 & 0.111 \\
T2F0.5 & 50.0 & 450.0 & 530.0 & 0.094 & 0.111 \\
T3F0.5 & 32.4 & 300.0 & 400.0 & 0.081 & 0.108 \\
T4F0.5 & 13.7 & 150.0 & 260.0 & 0.053 & 0.091 \\
T5F0.5 & 3.0 & 0.0 & 180.0 & 0.017 & 0.000 \\
\hline
\end{tabular}

\section{Discussion}

In 2014 and 2015 years, the amount of water applied to the plant in our study were $0-620 \mathrm{~mm}$ and $0-660 \mathrm{~mm}$, respectively. Kumar and Sahu (2013) reported that the water requirement of cabbage ranged from 107 to $268 \mathrm{~mm}$. Agrawal et al. (2018) determined that the amount of water used to the cabbage varied from 189 to $710 \mathrm{~mm}$. Seidel et al. (2017) informed that cabbages were applied 105-410 $\mathrm{mm}$ as irrigation water amounts in different irrigation treatments. Kiziloglu et al. (2007) specified that cabbages were applied $449.4 \mathrm{~mm}$ and $932 \mathrm{~mm}$ as irrigation water and the seasonal evapotranspiration in whole irrigation period. Wahome et al. (2009) stated that water applied for cabbage varied from 420 to $491 \mathrm{~mm}$ in different treatments and two mulch materials. Büyükcangaz (2018) reported that the cabbages were applied $70-520 \mathrm{~mm}$ as irrigation water and were determined $90-548 \mathrm{~mm}$ as crop water consumption in Bursa region. The results of irrigation water amount and crop water consumption values are compatible with previous cabbage studies (Wahome et al., 2009; Kumar and Sahu, 2013; Seidel et al., 2017; Pawar et al., 2017; Büyükcangaz, 2018; Agrawal et al., 2018)

The highest WUE and IWUE values for 2014 and 2015 years found as $0.110-0.101,0.118-0.118 \mathrm{~kg} \mathrm{~m}^{-3}$ and $0.101-$ $0.094,0.104-0.111 \mathrm{~kg} \mathrm{~m}^{-3}$, respectively. $\mathrm{T}_{1} \mathrm{~F}_{1.0}, \mathrm{~T}_{1} \mathrm{~F}_{0.5}$, $\mathrm{T}_{2} \mathrm{~F}_{1.0}$ and $\mathrm{T}_{2} \mathrm{~F}_{0.5}$ treatments have delivered the highest as WUE value. The results of water use efficiency were found to be similar when compared with the findings of different researchers (Himanshu et al. 2012; Kushwah and Dwivedi 2013; Seidel et al. 2017; Büyükcangaz 2018; Agrawal et al. 2018). Type of the cabbage, climate and soil structure affects the yield and quality values. Davis et al. (2008) reported that the difference between the values obtained in the study and the values obtained in the previous studies was caused by variety and cultural practices. The yield response factor $\left(\mathrm{k}_{\mathrm{y}}\right)$ values for cabbage in the experimental years were calculated as 1.20-1.19 and 1.23-1.18, respectively. The factor of $\mathrm{k}_{\mathrm{y}}$ (1.20-1.19 and 1.23-1.18) which is higher than 1.00 showed that cabbage was susceptible to water. The factor of $\mathrm{k}_{\mathrm{y}}$ also shows similarities with values found other researchers working on the same topic (Kushwah and Dwivedi, 2013; Seidel et al. 2017; Büyükcangaz 2018; Agrawal et al., 2018).

Fertigation together with drip irrigation provided high water use efficiency and fertilizer and chemicals could be applied in safe and desired concentrations in our study. Fertigation together with drip irrigation provided less water and fertilizer usage. However, a significant increase of crop production and quality was observed. The highest yield values in treatments which is applied as $\mathrm{F}_{1.0}: 10 \% 0$ $(100: 100: 100 \mathrm{NPK})$ and $\mathrm{F}_{0.5}: 50 \%$ (50:50:50 NPK) fertigation for the 2014-2015 trial years were obtained from $\mathrm{T}_{1} \mathrm{~F}_{1.0}$ and $\mathrm{T}_{1} \mathrm{~F}_{0.5}$ treatments and found as 73.2-70.6 $\mathrm{t}$ $\mathrm{ha}^{-1}$ and 68.4-66.8 $\mathrm{t} \mathrm{ha}^{-1}$, respectively. As expected, minimum yield values for 2014 and 2015 years were found from control $\mathrm{T}_{5} \mathrm{~F}_{1.0}$ and $\mathrm{T}_{5} \mathrm{~F}_{0.5}$ treatments $(5.0-3.0$ and 3.3 $-3.0 \mathrm{t} \mathrm{ha}^{-1}$ ), in which irrigation was not applied. Results of our study shows that the influence of deficit irrigation on yield was quite important. According to the head yield results, all treatments for 2014-2015 years were ranked as the different statistical groups. All treatments in 2014 and 2015 years were almost ranked as the different statistical groups from the standpoint of head height. In the first year of the experiment, head height, head diameter and head weight of fruit for two different fertigation levels were almost affected by deficit irrigation. In the second year of the experiment, head hight, head diameter and head weight of fruit for two different fertigation levels were affected by deficit irrigation. In 2014 and 2015 years, head height were affected by deficit irrigation. This result agrees with (Kumar and Sahu, 2013; Xu and Leskovar, 2014; Seciu et 
al., 2016; Büyükcangaz, 2018; Agrawal et al., 2018; Wu et al., 2020). Similar results were obtained in previous fertigation studies on cabbage (Kumar and Sahu, 2013; Xu and Leskovar, 2014; Seciu et al., 2016; Büyükcangaz, 2018; Agrawal et al., 2018; Wu et al., 2020).

The cabbage yield for 2014 and 215 years ranged between 73.2-3.0 and 68.4-3.0 $\mathrm{t} \mathrm{ha}{ }^{-1}$, respectively. According to the conclusions of this trial, it is observed that limited irrigation has an important effect on the yield of the cabbage. This result is in agreement with (Kumar and Sahu 2013; Xu and Leskovar, 2014; Seciu et al., 2016; Büyükcangaz 2018; Agrawal et al., 2018). As the irrigation water amounts decreased, the yield decreased significantly as well. The quality parameters of cabbage showed a same reaction to limited irrigation as beheld in the yield. The whole irrigation applications had higher values than the $\mathrm{T}_{5} \mathrm{~F}_{1.0}$ and $\mathrm{T}_{5} \mathrm{~F}_{0.5}$ treatments in which water is not used. These values show similarities with (Kumar and Sahu, 2013; $\mathrm{Xu}$ and Leskovar, 2014; Seciu et al., 2016; Büyükcangaz, 2018; Agrawal et al., 2018).

The fruit weight values of $\mathrm{T}_{1} \mathrm{~F}_{1.0}$ and $\mathrm{T}_{1} \mathrm{~F}_{0.5}$ treatments were higher compared to other irrigation treatments. In years of the trial, the maximum dry matter rate was observed in $\mathrm{T}_{5} \mathrm{~F}_{1.0}$ and $\mathrm{T}_{5} \mathrm{~F}_{0.5}$ treatments, while the minimum dry matter rate was found from $\mathrm{T}_{1} \mathrm{~F}_{1.0}$ and $\mathrm{T}_{1} \mathrm{~F}_{0.5}$ applications. With the obtained data, it can be decided that with the decrease in irrigation water deficit, there will be significant increases in the amount of dry matter. These results are consistent with those of (Kumar and Sahu, 2013; Xu and Leskovar, 2014; Seidel et al., 2017; Büyükcangaz, 2018; Agrawal et al., 2018).

\section{Conclusions}

In 2014-2015 study years, the amounts of irrigation water (IW) varied between 620-0 $\mathrm{mm}$ and 660-0 $\mathrm{mm}$, while the amounts of plant water consumption (ET) varied between $700-150 \mathrm{~mm}$ and 710-180 $\mathrm{mm}$. Crop yield response factors $\left(\mathrm{k}_{\mathrm{y}}\right)$ for the different irrigation and fertigation levels 2014 and 2015 years were calculated as 1.20-1.19 and 1.231.18 for cabbage, respectively. The factors of $\mathrm{k}_{\mathrm{y}}(1.20-1.19$ and 1.23-1.18) values bigger than 1,00 showed that the cabbage was susceptible to water. The crop yield response factors $\left(\mathrm{k}_{\mathrm{y}}\right)$ in two different fertigation $(100 \%$ and $50 \%$ fertigation) were close to each other in both years of the study. The highest yield decreases in all treatments were in $\mathrm{T}_{5} \mathrm{~F}_{1.0}$ and $\mathrm{T}_{5} \mathrm{~F}_{0.5}$ treatments, while the lowest yield decreases were in $\mathrm{T}_{1} \mathrm{~F}_{1.0}$ and $\mathrm{T}_{1} \mathrm{~F}_{0.5}$ periods. In our study, it was studied out those irrigation treatments considerable influences head yield, head height, head diameter, head weight and dry matter ratio. In 2014 and 2015 study years, the highest yield in different fertigation levels (100\% and $50 \%$ fertigation) were 73.2-70.6 $\mathrm{t} \mathrm{h}^{-1}$ and 68.4-66.8 $\mathrm{t} \mathrm{h}^{-1}$ and it was found in $\mathrm{T}_{1} \mathrm{~F}_{1.0}$ and $\mathrm{T}_{1} \mathrm{~F}_{0.5}$ treatments. The yield values closest to the highest yield values were obtained from $\mathrm{T}_{2} \mathrm{~F}_{1.0}$ and $\mathrm{T}_{2} \mathrm{~F}_{0.5}$ treatments. The lowest yields were also found as 5.0-3.0 tha 1 and 3.3-3.0 $\mathrm{t} \mathrm{ha}^{-1}$ in $\mathrm{T}_{5} \mathrm{~F}_{1.0}$ and $\mathrm{T}_{5} \mathrm{~F}_{0.5}$ treatments, respectively. The yield decreased significantly due to the irrigation water deficiency.

During the 2014 and 2015 study years, the product yield of the untreated $\mathrm{T}_{5} \mathrm{~F}_{1.0}$ and $\mathrm{T}_{5} \mathrm{~F}_{0.5}$ treatments were lower by 1364.0-2253.0\% and 1972.7-2126.7 \% compared to the $\mathrm{T}_{1} \mathrm{~F}_{1.0}$ and $\mathrm{T}_{1} \mathrm{~F}_{0.5}$ treatments. WUE and IWUE values of $\mathrm{T}_{1} \mathrm{~F}_{1.0}-\mathrm{T}_{2} \mathrm{~F}_{1.0}$ and $\mathrm{T}_{1} \mathrm{~F}_{0.5}-\mathrm{T}_{2} \mathrm{~F}_{0.5}$ treatments were the highest values $\left(0.110-0.110 \mathrm{~kg} \mathrm{~m}^{-3}, 0.118-0.118 \mathrm{~kg} \mathrm{~m}^{-3}\right.$ and $0.101-0.101 \mathrm{~kg} \mathrm{~m}^{-3}, 0.104-0.103 \mathrm{~kg} \mathrm{~m}^{-3}$ ). In water deficiency conditions, $\mathrm{T}_{2} \mathrm{~F}_{1.0}$ and $\mathrm{T}_{2} \mathrm{~F}_{0.5}$ treatments of cabbage are the most suitable periods for deficit irrigation and the yield and quality value decreases was the lowest in these treatments. As a result, of possible deficit irrigation in a semi-humid climate condition, it is necessary to plan carefully, and it is possible to say that the levels and times of the deficit irrigation and fertigation were significantly effective on cabbage yield. In cabbage irrigation, if the deficit irrigation treatment is obligatory, water deficiency should be planned only for $\mathrm{T}_{2} \mathrm{~F}_{1.0}$ and $\mathrm{T}_{2} \mathrm{~F}_{0.5}$ treatments. The water and fertigation deficiency shouldn't be applied in $\mathrm{T}_{1} \mathrm{~F}_{1.0}$ and $\mathrm{T}_{1} \mathrm{~F}_{0.5}$ treatments and irrigation and fertigation in these treatments should be exactly applied. In addition, in the irrigation planning to be done in similar climatic conditions may be benefited from crop yield response factor $\left(\mathrm{k}_{\mathrm{y}}\right)$ values. The results used to determine the amount of reduction in yield in response to the water and fertigation deficiency to be applied to the plant may be used in studies related to cabbage. $\mathrm{T}_{2} \mathrm{~F}_{1.0}(75 \%$ irrigation and $100 \%$ (100:100:100 NPK) fertigation level) and $\mathrm{T}_{2} \mathrm{~F}_{0.5}$ treatment (75\% irrigation and 50\% (50:50:50 NPK) fertigation level) can suggested as the most effective irrigation and fertigation level for cabbages that are inadequate in water and are drip irrigation in unheated greenhouse conditions.

\section{References}

Agrawal N, Tamrakar SK, Tripathi MP, Tiwari RB. 2018. Response of cabbage under different levels of irrigation and fertigation through drip. Int.J.Curr.Microbial.App.Sci. Special Issue (6): 750-759.

Anaç D, Eryüce N, Özkan CF, Şimşek M, Demirtaş EL, Asri F, Güven D, Ar1 N. 2019. Efficient of different potassium and sulfate fertilizer types on cabbage yield and quality. Electronic International Fertilizer Correspondent (e-ifc) No.56.pp.11-18 ref.29.

Anonymous. 2016a. The Annual report of Meteorological Station, Bursa, Turkey. www.mgm.gov.tr/verideğerlendirme /il-ve-ilceler-statistic.aspx?k

Anonymous. 2016b. The Meteorological Station of Greenhouse Application Area, Yenişehir-Bursa, Turkey. www.mgm.gov.tr/ verideğerlendirme/il-ve-ilceler-statistic.aspx?k

Anonymous 2020. The Properties of Grandslam F1. https://sakata.co.za/product/grandslam-f1-hybrid-freshmarket-cabbage/_Accessed 25 June 2020.

AOAC. 2000. Association of Official Analytical Chemistry, Official methods of analysis, 17th ed. AOAC, Washington, DC, USA.

Ashraf SO, Ewees MSA. 2008. The possible use of humic acid incorporated with drip irrigation system to alleviate the harmful effects of saline water on tomato plants. - Fayoum J. Agric. Res. \& Dev. 22(1): 1-19.

Bayraktar K. 1981. Vegetable Growing. Volume 2 (Culture Vegetables). Faculty of Agriculture Publications of Ege University, No:169, Bornova, İzmir, Turkey.

Bos MG. 1980. Irrigation efficiencies at crop production level. ICID Bull.29: 18-25

Bos MG. 1980. Irrigation efficiencies at crop production level. ICID Bull.29: 18-25.

Büyükcangaz H. 2018. Deficit irrigation effects on Cabbage (Brassicaceae Oleracea var. Capitata L. Grandslam F1) yield and unheated greenhouse condition. Turkish Journal of Agriculture-Food Science and Technology, 6 (9): 1251-1257. 
Çetin Ö, Akalp E. 2019. Efficient use of water and fertilizers in irrigated agriculture: drip irrigation and fertigation. Acta Horticulturae et Regiotecturae 2, pp.97-102.

Davis AR, Webber CL, Perkins-Veazie P, Ruso V, Lopez Galarza S, Sakata Y. 2008. A Review of production systems on watermelon quality. Roceedings of the IXth EUCARPIA Meeting on 98 Genetics and Breeding of Cucurbitaceae (M. PITRAT, editor), INRA, Avignon, France, 515-520.

Doorenbos J, Kassam AH. 1979. Yield response to water. FAO Irrigation and Drainage Paper No. 33, Rome.

Erdem T, Arın L, Erdem Y, Polat S, Deveci M, Okursoy H, Gültaş HT. 2010. Yield and quality response of drip irrigated broccoli (Brassica oleracea L. var. italica) under different irrigation regimes, nitrogen applications and cultivation periods. Agric.Water Manag. 97, 681-688.

FAOSTAT. 2016. Food and Agriculture Organization Corporate Statistical Database. Available from: http://www.fao.org/ faostat/en/\#data/QC (Accesses 2020)

Himanshu SK, Kumar S, Kumar D, Mokhtar A. 2012. Effects of lateral spacing and irrigation scheduling on drip irrigated cabbage (Brassica oleracea) in a semiarid region of India. Research Journal of Engineering Sciences 1(5): 1-6.

İşcan S, Uyan A, Tepeli E, Alaç V, Sarıtaş H, Gökalp Y, Çınar M, Çelik A. 2002. Fertilizer applications with irrigation systems. Ministry of Agriculture and Rural Areas, The Management of Adana Agricultural Production Enterprise and Personnel Training Center. Pub. No: 6 Adana, Turkey.

Kızıloğlu FM, Turan M, Sahin U, Angin I, Anapali O, Okuroglu M. 2007. Effects of wastewater irrigation on soil and cabbage plant chemical properties. J. Plant Nutr. Soil Sci. 170: 166172. DOI: 10.1002/jpln.200621971.

Kızıloğlu FM, Turan M, Şahin U, Kuslu Y, Dursun A. 2008. Effects of untreated and treated wastewater irrigation on some chemical properties of cauliflower (Brassica olerecea L. var. botrytis) and red cabbage (Brassica olerecea L. Rubra) grown on calcareous soil in Turkey. Agr.Water Manag. 95: 716-724.

Kumar P, Sahu RL. 2013. Effects of irrigation and fertigation levels on cabbage. An Asian Journal of Soil Science 8(2): 270-274.

Kushwah SS, Dwivedi YC. 2013. Effect of different methods of irrigation and moisture regimes on yield and water economy in cabbage (Brassica oleracea L. var. capitata). Asian J. Hort 8(1): 43-45.
Nikzad M, Kumar JSA, Anjanappa M, Amarananjundeswara H, Dhananjaya BN, Basavaraj G 2020. Effect of fertigation, levels on growth and yield of cabbage (Brassica oleracea 1 . var.capitata). Int.J.Curr.Microbiol.App.Sci. 9 (1): 1240-1247.

Pawar GS, Kale MU, Lokhande JN. 2017. Response of aquacrop model to different irrigation for irrigated cabbage. Agric Res (March 2017) 6(1):73-81.

Seciu AM, Oancea A, Gaspar A, Moldovan L, Craciunescu O, Stefan L, Petrus V, Georgescu F. 2016. Water use efficiency on cabbage and cauliflower treated with a new biostimulant composition. Agriculture and Agricultural Science Procedia 10: 475-484. https://doi.org/10.1016/j.aaspro.2016.09.019.

Seidel SJ, Werish S, Schütze N, Laber H. 2017. Impact of irrigation on plant growth and development of white cabbage. Agricultural Water Management, 187: 99-111.

Steel RGD, Torrie JH. 1980. Principles and procedures of statistics. A biometrical approach. McGraw-Hill, NewYork, pp.186-187.

Stewart JI, Misra RD, Pruitt WO, Hagan RM. 1975. Irrigating corn and sorghum with a deficient water supply. Trans. ASAE, 18: 270-280.

TUİK 2016. http://www.tuik.gov.tr/PreTablo.do?alt_id=1001

TIIK 2017. https://biruni.tuik.gov.tr/medas/?kn=92\&locale=tr

Vural H, Eşiyok D, Duman İ. 2000. Cultivated vegetables (Kültür sebzeleri), Ege University press, 440 p. (In Turkish).

Wahome PK, Shongwe V, Mbewe DN. 2009. Response of cabbage (Brassica oleraceae var. capitata) to mulching and different irrigation regimes. Am-Euras. J. Agric \&. Environ. Sci. 6(6): 662-669.

Wanjura DF, Hatfield JL, Upchurch DR. 1990. Crop water stress index relationships with crop productivity. Irrig. Sci. 11: 9399.

Wu X, Bai M, Li Y, Du T, Zhang S, Shi Y, Liu Y. 2020. The Effects of fertigation on cabbage (Brassica oleracea L. Var. Capitata) grown in a greenhouse. Water (12) 1076; doi:10.3390/w12041076.

$\mathrm{Xu} \mathrm{C,} \mathrm{Leskovar} \mathrm{DI.} \mathrm{2014.} \mathrm{Growth,} \mathrm{physiology} \mathrm{and} \mathrm{yield}$ responses of cabbage to deficit irrigation. Hort. Sci., 41(3):138-146.

Zhang H, Wang X, You M, Liu C. 1999. Water-yield relations and water-use efficiency of winter wheat in the North China Plain. - Irrigation Science 19: 37-45 